\title{
Estatais e ajuste fiscal: \\ uma análise da contribuição das empresas federais para o equilíbrio macroeconômico ${ }^{1}$
}

\author{
Sérgio Wulff Gobetti ${ }^{2}$
}

\begin{abstract}
Resumo
Este artigo apresenta uma análise histórica e empírica das transformações ocorridas na gestão das empresas estatais brasileiras durante os últimos 20 anos. O principal insight do estudo é mostrar como as empresas federais, consideradas vilãs da crise fiscal dos anos 1980 - por terem sido usadas pela ditadura militar para sua política de endividamento externo -, assumiram um papel decisivo para o equilíbrio fiscal e macroeconômico no período recente. Estimamos que a contribuição efetiva das estatais para o superávit primário do setor público esteja acima dos 50\%, contabilizando as contribuições indiretas, como dividendos e royalties. Além disso, calculamos que a fatia das estatais nos pagamentos de tributos a União, estados e municípios cresceu de 7,7\% em 1999 para 14\% em 2005-06, respondendo por cerca de 40\% do aumento da carga tributária. Também encontramos, aqui, evidências de que os investimentos das estatais no Brasil contribuíram para compensar o aperto fiscal e monetário entre 2002 e 2004.
\end{abstract}

Palavras-chave: Empresas estatais - Brasil; Superávit primário; Carga tributária; Investimentos.

\section{Abstract \\ State owned enterprises and fiscal adjustment: an analysis of the contribution of the federal companies to macroeconomic equilibrium}

This article expose a historical and empirical analysis of the transformations in the administration of the Brazilian state owned enterprises during the last 20 years. The main insight of the study is to show how the federal companies, considered villains of the fiscal crisis in the 80's - because its manipulation by military dictatorship to his foreign indebtedness policy -, assumed a decisive role in fiscal and macroeconomic equilibrium in the recent period. We estimate that the effective contribution of federal companies to primary surplus has been above 50\%, accounting the indirect contributions, like dividends and royalties. Moreover, we calculate that the share of this enterprises in tax revenues of federal, state and municipal governments have grown from 7,7\% in 1999 to $14 \%$ in 2005-06, representing around $40 \%$ of the increase in tax rate. We also found evidences, here, that the investments executed by those companies has contributed to compensate the fiscal and monetary contraction between 2002 e 2004.

Key words: Public companies - Brazil; Primary surplus; Tax rate; Investments.

JEL E62, H11, H25, H54, L32.

(1) Trabalho recebido em abril de 2008 e aprovado em dezembro de 2008.

(2) Técnico de Planejamento e Pesquisa do Instituto de Pesquisa Econômica Aplicada (Ipea), Brasília, DF, Brasil. E-mail: <swgobetti@gmail.com>. 
Sérgio Wulff Gobetti

\section{Introdução}

Grande parte do desenvolvimento econômico brasileiro contemporâneo deve-se às empresas estatais. Por bem ou por mal, foram elas que puxaram o crescimento da economia nos anos 1970, enquanto o mundo era atingido pelo choque do petróleo. Para conseguir manter a "economia em marcha forçada" (Castro; Souza, 1985) e, ao mesmo tempo, equilibrar o balanço de pagamentos, o governo militar utilizou uma estratégia de crescimento com endividamento que colocou o país em um novo patamar de industrialização - acima daquele de outros latino-americanos, como a Argentina -, mas também originou uma série de desequilíbrios (como o fiscal, por exemplo) que se perpetuam até os dias de hoje. ${ }^{3}$ Ao apogeu das estatais, marcado por uma taxa de investimento superior a $4 \%$ do PIB nos anos 1970, seguiu-se nos anos 90 uma fase de profunda reestruturação ou desarticulação das atividades produtivas do Estado, com a privatização e abertura de capital de grandes empresas, como a Companhia Vale do Rio Doce e a Petrobras. Entre 1999 e 2000, como reflexo desse processo, os investimentos das estatais caíram para o menor nível dos últimos 40 anos: $0,85 \%$ do PIB. ${ }^{4}$

Passados menos de 10 anos desde as privatizações, entretanto, ao contrário de muitos prognósticos que apontavam a tendência de esvaziamento ou enfraquecimento das estatais remanescentes, podemos constatar exatamente o contrário: as empresas sob controle majoritário do governo não só estão incrementando sua contribuição para a formação bruta de capital fixo (FBCF), tendo atingido a marca de $1,41 \%$ do PIB em 2006, como estão cumprindo um papel decisivo para o ajustamento fiscal do setor público. Conforme será demonstrado ao longo deste artigo, a participação das estatais no superávit primário é crescente e já supera os $50 \%$, se considerarmos os dividendos e compensações financeiras pagas ao Tesouro e redistribuídas pelos três níveis de governo - como os royalties.

A recuperação da taxa de investimento das estatais é tanto mais importante para o equilíbrio macroeconômico se considerarmos que as aplicações diretas das administrações públicas em FBCF, segundo o conceito do IBGE, sofreram substancial queda no período recente, entre 2003 e 2004, devido ao aumento da meta de superávit primário. Ou seja, as empresas públicas - notadamente a Petrobras - compensaram parcialmente a retração dos investimentos do próprio governo, amenizando o efeito recessivo pró-cíclico da política monetária e fiscal no início do governo Lula.

(3) Ver Bielschowsky e Mussi (2005) para um apanhado histórico do pensamento desenvolvimentista no Brasil.

(4) Série histórica reconstituída a partir de dados do Centro de Estudos de Economia e Governo (CEEG) do Instituto Brasileiro de Economia (IBRE/FGV-RJ) reportados no Ipeadata. 
Apesar de algumas semelhanças, o papel desempenhado pelas estatais no cenário econômico não é o mesmo da década de 1970. Nos últimos 10 anos, o número de empresas estatais se reduziu, mas uma série de novas rotinas e práticas de governança de empresas de capital aberto foi adotada. Enquanto no passado as estatais já foram utilizadas até mesmo para fins de controle de preços, em anos recentes algumas delas inclusive lucraram muito com o crescimento dos preços, como no caso do petróleo produzido pela Petrobras, que segue referenciado no mercado internacional.

Este artigo será dividido em cinco seções, incluindo esta introdução. $\mathrm{Na}$ primeira seção, abordamos, do ponto de vista teórico e histórico, o papel que as estatais tiveram no desenvolvimento do capitalismo brasileiro, situando como elas foram usadas pelo governo militar para endividar-se na década de 1970; na segunda seção, fazemos uma discussão sobre os resultados fiscais do processo de privatização e, ao mesmo tempo, apresentamos evidências de que a contribuição fiscal das estatais remanescentes desde 2000 já é bem superior à receita de alienação de empresas entre 1991 e 2002; na seção 3, analisamos a gestão das estatais, abordando temas como o perfil de gastos das empresas, seus resultados financeiros e o papel dos seus investimentos para a macroeconomia; finalizamos com a seção 4 e as conclusões.

\section{Contexto: as estatais e a história do capitalismo brasileiro}

Uma das características marcantes do desenvolvimento do capitalismo no Brasil é o significativo papel desempenhado pelo Estado na indução do processo de industrialização, sobretudo a partir dos anos 1940 (Furtado, 1979). Esse papel foi exercido não apenas por meio das atribuições fiscais e monetárias do Estado, ou de sua função de provedor dos chamados bens públicos, mas também e principalmente, conforme Serra (1984, p. 68), através da: i) definição, articulação e sustentação financeira dos grandes blocos de investimento que determinaram as principais modificações estruturais da economia no pós-guerra; ii) criação da infraestrutura e produção direta dos insumos intermediários indispensáveis à industrialização pesada.

Tal característica expressa uma especificidade de países capitalistas de desenvolvimento tardio, ${ }^{5}$ como o Brasil, que ingressaram na era industrial quando as bases técnicas e financeiras das atividades manufatureiras já eram relativamente complexas, implicando grandes dimensões de plantas e elevadas exigências tecnológicas. Nesse contexto, os grandes projetos industriais têm uma forte relação de interdependência, obrigando que sua implementação fosse feita de forma

(5) Hirschman (1958) batizou esse tipo de país como "latecomers"; Cardoso de Mello (1982) desenvolve o conceito para o Brasil. 
conjunta, em razão do risco de torná-los inviáveis devido aos problemas de capacidade ociosa e de equilíbrio do balanço de pagamentos.

No Brasil, a implementação dessa estratégia de industrialização esteve associada às empresas estatais desde o início, como no período pós-guerra, quando o governo federal começou a colocar em operação empreendimentos voltados à produção de minérios de ferro, soda cáustica, aço e aços especiais. Essas iniciativas foram combinadas com investimentos nas áreas de transporte rodoviário e de energia elétrica, assim como políticas macroeconômicas voltadas a proteger a produção doméstica.

Em poucos anos, esses empreendimentos e outros que a eles se seguiram, como a criação da Petrobras, em 1953, e do Banco Nacional de Desenvolvimento Econômico (BNDE), abriram um importante ciclo de crescimento industrial, só interrompido por um breve período, na década de 1960, antes que se iniciasse o chamado "milagre econômico". Nos anos 1970, entretanto, quando a crise do petróleo se manifestou e levou diversos países a adotarem políticas macroeconômicas mais restritivas, o governo brasileiro tentou manter o ritmo dos investimentos, utilizando as estatais para viabilizar seu plano de crescimento com endividamento. ${ }^{6}$

\subsection{O uso das estatais como instrumento de endividamento}

Conforme Werneck (1986), a decisão do governo de usar as estatais para fechar o balanço de pagamentos adveio, inicialmente, da mera decisão de explorar as vantagens comparativas desse setor na captação de recursos no Exterior. Naquele momento de crise, havia resistência no sistema financeiro internacional de oferecer empréstimos com a finalidade específica de financiar déficits em transações correntes, mas, curiosamente, o mesmo não ocorria com relação ao financiamento de projetos concretos de investimentos, particularmente de grandes estatais, como eram os do II PND (1974-78).

Dado esse quadro, o governo militar passou a induzir o financiamento dos megaprojetos do II PND através da captação de recursos externos, independentemente da real necessidade de divisas envolvida nesses investimentos. Na mesma linha política, houve um cerceamento crescente do acesso das empresas estatais a fontes internas de capital, como o mercado primário de ações, e adotouse uma política pouco realista de reajuste das tarifas e bens e serviços por elas

(6) De acordo com Coutinho e Belluzzo (1982, p. 159), a partir de 1974 a política econômica buscava conjugar objetivos irreconciliáveis, quais sejam, sustentar altas taxas de crescimento, reverter a aceleração inflacionária e equilibrar o balanço de pagamentos. Haveria uma "contradição inequívoca", por exemplo, entre a política de gasto e investimento público, ambiciosa e expansionista, e a política de crédito e financiamento, contracionista. 
produzidos, o que, além de conveniente para a redução das pressões inflacionárias, também sufocava a capacidade de autofinanciamento das empresas. ${ }^{7}$

Posteriormente, quando o prenúncio de uma grave crise de balanço de pagamentos, ao final dos anos 1970, tornou o risco cambial excessivamente alto para o setor privado, as estatais foram mais uma vez coagidas a continuarem se endividando, unicamente para assegurar um fluxo adequado de recursos externos. ${ }^{8}$ Ao mesmo tempo, foram criados mecanismos que permitiram que o risco cambial de boa parte da dívida externa contraída pelo setor privado fosse assumido pelo Estado.

Em 1982, quando a crise cambial adveio, segundo Werneck (1986) e Cruz (1984), o setor público - aí incluindo as estatais - acabou absorvendo todo o ônus do ajuste interno à crise da dívida externa. Em vez de socializar com o setor privado esse ônus, via aumento da carga tributária ou realinhamento dos preços públicos, o governo optou pelo endividamento interno, o que agravou as dimensões da crise fiscal e do ajuste necessário para superá-lo.

Para que a estatização paulatina da dívida externa não viesse a gerar as dificuldades financeiras que vieram gerar no âmbito do setor público, teria sido necessário um aumento concomitante da participação da renda disponível do setor público no PIB, o que quase certamente envolveria uma elevação razoável da carga tributária bruta de forma a carrear ao setor público recursos que correspondessem à contrapartida em cruzeiros dos crescentes encargos com o serviço da dívida externa. À socialização da dívida externa teria que haver correspondido uma socialização dos serviços desta mesma dívida (Werneck, 1986, p. 558).

\subsection{As primeiras tentativas de controle das estatais e as contradições de política econômica durante a ditadura}

A crescente inserção econômica das estatais na década de 1970, sobretudo a partir do II PND, gerou um acúmulo de tensões políticas e divergências dos interesses privados com as novas políticas setoriais, o que desatou uma intensa controvérsia a respeito do papel do Estado e, particularmente, de suas empresas. $\mathrm{O}$ governo, pressionado pelo empresariado nacional, não desistiu de sua empreitada, respondendo com uma série de medidas formais de controle sobre suas empresas: estabeleceu para elas o imposto de renda, proibiu a criação de novas subsidiárias sem autorização presidencial, limitou o acesso à bolsa de valores e buscou cercear suas operações na esfera financeira (Coutinho; Belluzzo, 1984).

(7) A título de ilustração, outro estudo de Werneck (1986) revela que os únicos preços públicos que apresentaram aumento real entre 1979 e 1984 foram os de derivados de petróleo, cujo índice de preços por atacado, quando deflacionado pelo IGP-DI, cresceu $60 \%$. Os preços reais dos produtos siderúrgicos caíram $50 \%$ no mesmo período, a tarifa de energia elétrica, $40 \%$, e as tarifas telefônicas, $60 \%$ em média.

(8) Cruz (1984) oferece um panorama completo sobre o processo de endividamento externo. 
Sérgio Wulff Gobetti

Posteriormente, entre 1976 e 1978, quando a ala ortodoxa de Mário Henrique Simonsen assumiu o controle do Ministério da Fazenda e adotou uma série de medidas para conter a demanda agregada, as grandes empresas estatais escaparam dos cortes impostos à administração direta e indireta, mas foram submetidas a um sistema mais rígido de controle dos seus investimentos, através da aprovação prévia de um orçamento para o ano seguinte na esfera da Secretaria de Planejamento (Seplan).

Nesse momento, o governo também operou a liberação total da taxa de juros, reforçando as condições para a entrada maciça de empréstimos externos. Os efeitos recessivos dessa medida logo foram sentidos, porém os resultados da balança comercial melhoraram com a contenção das importações e o racionamento de gasolina. Aos poucos, o governo conseguiu contornar as críticas do empresariado à política restritiva, com abandono do II PND, mas a forte elevação da taxa de juros amplificou crescentemente o "hiato" financeiro na operação da dívida pública (utilizada para financiar a conversão do saldo líquido dos recursos entrantes).

De acordo com Coutinho e Belluzzo (1984), a política contencionista aplicada desta forma e, ao mesmo tempo, levada de roldão pela expansão creditícia originada dos empréstimos no Exterior não somente revelar-se-ia inepta para atingir os seus objetivos, como tenderia a desintegrar a própria efetividade dos instrumentos de intervenção. Do lado do gasto e do investimento público, as repetidas tentativas de impor cortes e controles mais rígidos foram sendo derrotadas pela necessidade de utilizar as empresas estatais, especialmente a partir de 1978, como tomadoras de grande escala no "euromoedas".

O processo de contenção do dispêndio público funcionou de modo bastante desigual entre os setores da administração indireta, com uma contração efetiva nas áreas de infraestrutura, transportes, telecomunicações e gastos sociais, enquanto as empresas estatais mais poderosas (do Setor Produtivo Estatal) utilizavam esta válvula de escape para financiar a sustentação de suas inversões e contribuíam, desta forma, para frustrar a intenção recessionista da política econômica (Ibid., p. 165).

No primeiro semestre de 1979, diante do coro de críticas pela inflação ascendente e pela elevada taxa de juros, a nova administração do general Figueiredo resolveu concentrar ainda mais os poderes de decisão da área econômica. O ministro Simonsen foi transferido da pasta da Fazenda para a Seplan, que passou a coordenar o Conselho Monetário Nacional e o orçamento monetário, além de sua função de controle do gasto e investimento público. Houve, então, uma perceptível mudança de orientação, com a adoção de medidas para desacelerar o fluxo de endividamento externo, reduzir os incentivos fiscais e 
cortar os gastos e investimentos das estatais, mas nada foi feito em relação à circulação financeira hiperinflada e à taxa de juros elevada.

Em agosto do mesmo ano ocorre uma reviravolta, e Delfim Netto assumiu a Seplan, anunciando sua disposição de restaurar as finanças do Estado e de implementar uma política de inflação "corretiva" para recompor a capacidade financeira das empresas públicas. Do ponto de vista prático, o pacote de medidas incluiu a criação de uma Secretaria Especial para as Empresas Estatais, a Sest, com o objetivo de impor um controle mais rígido sobre o setor.

Em 1980, o governo também decretou um corte generalizado de $15 \%$ nos investimentos programados pelas estatais para aquele ano, acompanhado de cortes nas importações e outros dispêndios em divisas do setor público. A preocupação em centralizar o orçamento das estatais decorre do crescimento do déficit público via válvulas de escape como as estatais, os subsídios e incentivos fiscais.

Braga (1982) questiona, entretanto, o argumento de que esses gastos estariam gerando inflação na medida em que, dada a capacidade ociosa da economia, os investimentos públicos teriam contribuído para expandir a demanda agregada, gerando mais massa de salários, lucros e, portanto, receitas públicas. $\mathrm{O}$ autor argumenta que o desenvolvimento das empresas estatais "é a expressão de uma dada participação orgânica do Estado no desenvolvimento capitalista" (Ibid., p. 196):

Como empresas que são, seus gastos não podem ser analisados do mesmo modo como o são os dispêndios de natureza fiscal incluídos no Orçamento Geral da União. Estes estão ancorados nas receitas tributárias, bem como nos mecanismos da dívida pública de médio e longo prazos. Já as estatais, enquanto empresas, podem lançar mão dos mecanismos gerais de crédito para suportar seus planos de expansão desde que seus lucros suportem no tempo o endividamento empreendido (Ibid., p. 200).

O ponto essencial na argumentação do autor é que, como empresas capitalistas, as estatais podem se endividar para crescer, contribuindo para a expansão da formação bruta de capital e do emprego, sem exercer necessariamente pressão inflacionária, uma vez que os dispêndios de investimento geram, simultaneamente, os lucros (e as poupanças) que globalmente os financiam. Braga admite, entretanto, que "por outras razões que não apenas sua expansão" (Ibid, p. 200), as empresas estatais elevaram substancialmente o seu endividamento.

Todas essas polêmicas envolvendo o controle das estatais suscitaram, ao longo da década de 1980, uma intensa discussão sobre a necessidade de impor a "unicidade orçamentária" do setor público brasileiro, o que veio a se materializar na Constituição de 1989. Com a nova carta magna, os orçamentos fiscal, monetário e das empresas estatais foram finalmente integrados, inaugurando uma nova fase (analisada a seguir). 
Sérgio Wulff Gobetti

\section{Estatais e equilíbrio fiscal}

\subsection{Um balanço atualizado das privatizações}

A crise fiscal na qual o Brasil se viu submerso nos anos 1980, em decorrência do processo de endividamento externo e interno e do manejo inadequado das estatais, transformou as empresas do governo numa das principais vilãs dos problemas econômicos enfrentados pelo país e em símbolo de ineficiência. Paralelamente a esse ambiente interno, constituiu-se mundialmente um forte movimento, coordenado pelos organismos internacionais, a partir do Consenso de Washington, em favor de reformas estruturais que passassem pelo redimensionamento do Estado e de sua inserção econômica.

No Brasil, esse movimento se materializou, logo no início dos anos 1990, no lançamento de um Programa Nacional de Desestatização (PND), que tinha por objetivo transferir ao setor privado a maior parte das atividades empresariais exercidas pelo Estado. Embora o debate ideológico sobre as privatizações frequentemente estivesse pautado por um argumento, por parte dos liberais, a favor de uma maior eficiência do setor privado, foram principalmente as razões de natureza fiscal e macroeconômica que influenciaram a decisão do governo brasileiro de lançar mão da venda de suas empresas. ${ }^{9}$ Ou seja, um dos objetivos centrais do PND, segundo a própria legislação que o instituiu, era obter uma receita substantiva que permitisse reduzir o endividamento público.

Inicialmente, entre 1990 e 1994, as privatizações atingiram 33 empresas e renderam uma receita de apenas US\$ 8,6 bilhões; porém, a partir de 1995, no governo FHC, o programa de desestatização foi ampliado e, até 2002, gerou mais US\$ 78,6 bilhões de receita. Adicionalmente, o governo transferiu US\$18,1 bilhões de dívidas de suas empresas aos novos controladores, totalizando um resultado de US\$105,3 bilhões, conforme os relatórios de atividade do BNDES (2005).

O auge do processo de privatização se deu entre os anos de 1997 e 1999 (como se vê no Gráfico 1, a seguir), quando foi alienado o controle acionário da Companhia Vale do Rio Doce (CVRD), uma das maiores empresas produtoras de minério de ferro do mundo, por um montante de US\$ 5,4 bilhões, e das subsidiárias do sistema Telebrás, por US\$29,8 bilhões. Posteriormente, em 2000, o governo vendeu as ações ordinárias da Petrobras que excediam o mínimo necessário à manutenção do controle acionário nas mãos da União, totalizando uma receita equivalente, na época, a US $\$ 4,8$ bilhões.

(9) Para Pinheiro (1999), a privatização no Brasil atendeu mais aos imperativos do esforço de estabilização do que a um processo de conversão ideológica, ainda que esse não tenha sido a sua única motivação. 
Receitas das privatizações (1991-2002)

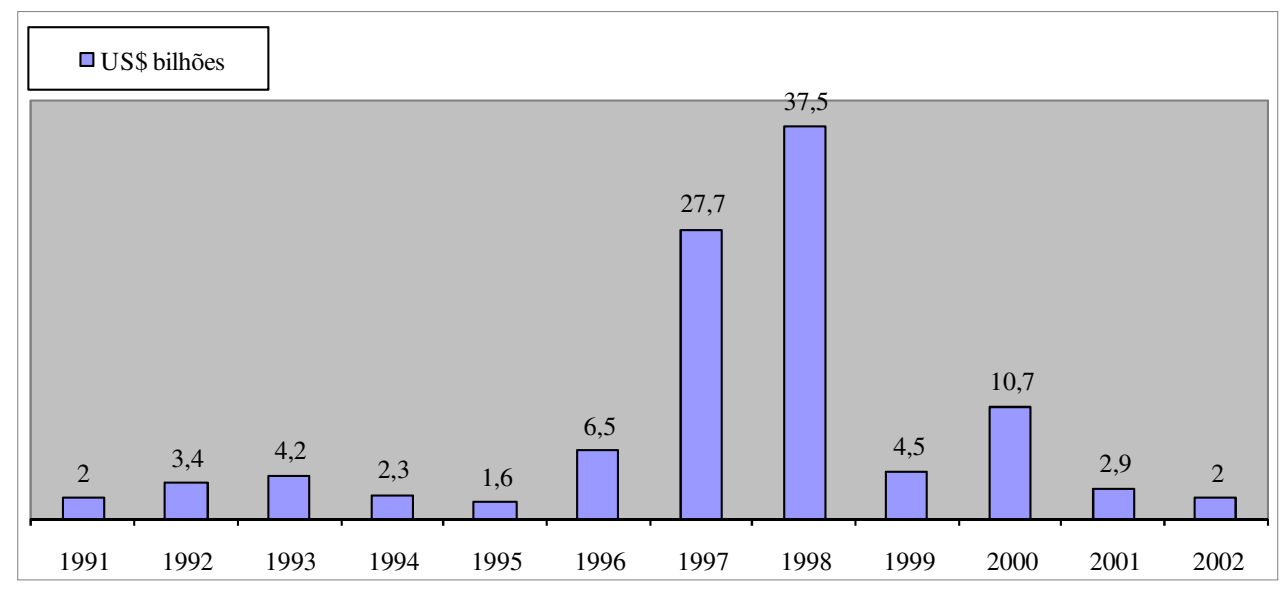

Fonte: BNDES (2005).

Ao todo, cerca de 110 empresas estatais federais e 28 estaduais foram privatizadas ou tiveram parte de suas ações vendidas como resultado desse processo. Passada uma década, algumas se tornaram ícones de sucesso, como a CVRD; outras, são lembradas principalmente pelo benefício que trouxeram aos consumidores - como a modernização do setor de telefonia -, apesar de todos os problemas de regulação ainda existentes. Do lado das empresas que permaneceram sob controle majoritário da União, entretanto, também é possível enumerar experiências bem sucedidas de progresso e lucratividade, como o da Petrobras, por exemplo, que é hoje uma das maiores do setor petrolífero do mundo, o que mostra que o problema central para a eficiência não é o da natureza pública ou privada, mas sim o da forma como são administradas.

Além de abrirem seu capital, várias empresas estatais têm sido submetidas a novas práticas de governança corporativa, tendendo a aprimorar os mecanismos pelos quais a União exerce seu poder de controlador principal. É claro que a influência política dos grupos de interesse ainda é grande nas empresas, ${ }^{10}$ mas essa característica não é hoje uma exclusividade do espaço estatal, sendo possível controlá-la sem a necessidade de privatização.

Diante dessas considerações preliminares, podemos nos perguntar: afinal, as privatizações foram ou não um bom negócio para o setor público? A resposta a essa pergunta não é trivial, porque depende do ângulo abordado, sendo possível fazer aqui alguns importantes questionamentos à luz de velhas e novas evidências.

(10) Para Velasco (1999, p. 207-208), as privatizações serviriam justamente para reduzir a quantidade de objetos estatais passíveis de captura dos grupos de interesse. 
Para Pinheiro e Giambiagi (2000), por exemplo, as privatizações no Brasil não só foram influenciadas por objetivos macroeconômicos, como também teriam contribuído para o sucesso do plano de estabilização econômica do governo Fernando Henrique Cardoso. Segundo eles, a privatização "limita a liberdade do governo para adotar políticas intervencionistas, forçando-o a empregar uma estratégia de desenvolvimento mais voltada para o mercado" (Idem, p. 15). No caso brasileiro, isso teria representado "um importante papel na sinalização do compromisso de reduzir a participação do Estado na economia, sem a qual o Brasil poderia ter mais dificuldade no acesso aos mercados de capital estrangeiros" (Ibid., p. 16).

Como parte desse argumento, os autores sustentam que as privatizações impediram que a dívida pública fugisse ao controle do governo, sendo também fundamentais para atrair investimentos diretos estrangeiros e, dessa forma, financiar o enorme déficit em conta corrente gerado no início do Plano Real. Esse tipo de justificativa para as privatizações, em nossa opinião, só é válido por completo se assumirmos que não havia outro tipo de política econômica - não ancorada na alta taxa de juros e na sobrevalorização da moeda, geradora dos déficits comerciais - possível de implementar, naquele momento, para controlar a inflação.

Além disso, de acordo com Pinheiro e Giambiagi (2000), as privatizações teriam a capacidade de gerar "benefícios fiscais permanentes, que se calcula serem substanciais" (Ibid., p. 26), embora num primeiro momento eles não parecessem ser expressivos. O raciocínio completo, então, seria o seguinte:

Esperava-se que a privatização das EEs trouxesse um ganho fiscal permanente, como resultado de uma lucratividade futura mais elevada em mãos privadas, o que incentivaria os compradores a pagar mais do que elas valiam para o governo. Essa maior lucratividade também geraria um aumento das receitas tributárias. Pelo mesmo raciocínio, a privatização livraria o governo da obrigação de financiar o investimento nas empresas privatizadas e, dessa forma, constituiria um alívio fiscal imediato. Finalmente, o uso das receitas da privatização para amortizar a dívida pública traria benefícios fiscais, já que a taxa de juros sobre a dívida pública era muito mais alta do que a taxa de retorno obtida pelo governo como acionista (Ibid., p. 26-27).

Passados dez anos do auge do processo de privatização, entretanto, há indícios de que elas podem não ter sido um negócio tão bom do ponto de vista fiscal, nem ter proporcionado ganhos fiscais tão permanentes como se esperava. ${ }^{11}$ Em primeiro lugar, a receita proveniente das privatizações não cumpriu o objetivo de reduzir o endividamento, por inconsistências da política macroeconômica notadamente, a elevada taxa real de juros que vigorou desde o início do Plano

(11) Para alguns autores, como Mello (1994), a perspectiva desde o início do processo era de que a contribuição da privatização para o ajuste fiscal não seria grande, e sim seus impactos microeconômicos. 
Real. Entre 1995 e 2003, a dívida líquida do setor público cresceu de 27,98\% para $52,36 \%$ do PIB, como podemos ver na Tabela 1 (abaixo), que reproduz dados do Banco Central. $\mathrm{O}$ efeito redutor das privatizações sobre o endividamento não passou de 3,65\% do PIB até 2003 (ou 2,71\% do PIB, se avaliado em valores de 2007), não compensando nem mesmo o efeito contrário do ajustamento patrimonial (esqueletos), que era de 5,35\% do PIB no mesmo ano.

Em segundo lugar, os valores obtidos com a alienação de algumas empresas revelam ter sido baixos, como é o caso da CVRD, quando comparamos o seu preço de venda com seus lucros atuais. É claro que sempre se poderá argumentar que o atual sucesso da empresa se deveu aos ganhos de eficiência e produtividade decorrentes da privatização, mas também é possível fazer conjecturas sobre qual teria sido o ganho decorrente da manutenção do controle acionário nas mãos do governo, como ocorreu com a Petrobras.

Na realidade, os lucros tanto da Petrobras quanto da CVRD não se devem exclusivamente à forma como as duas empresas estão sendo geridas, sob controle ou não do governo, mas também a um conjunto de condições macroeconômicas internas e externas favoráveis à sua expansão, tais como os preços das suas commodities e o atual momento de estabilidade e crescimento pelo qual passa a economia brasileira.

Tanto em um caso quanto em outro, a lucratividade das empresas está proporcionando consideráveis ganhos tributários para o setor público (como será demonstrado mais adiante). Essa situação favorável tanto às empresas estatais quanto às privatizadas torna a polêmica sobre o balanço do PND inconclusa. Mas o ponto essencial no qual queremos chegar, independentemente de hipóteses sobre como estariam hoje algumas empresas caso não tivessem sido completamente privatizadas, é dimensionar a real contribuição fiscal das estatais remanescentes. Antes disso, porém, apresentamos na seção seguinte uma breve radiografia do universo atual das estatais federais.

Tabela 1

Evolução da dívida líquida do setor público (\% PIB)

\begin{tabular}{l|r|r|r|r|r|r|r|r|r|r|r}
\hline Especificação & 1995 & 1996 & 1997 & 1998 & 1999 & 2000 & 2001 & 2002 & 2003 & 2006 & $2007 *$ \\
\hline $\begin{array}{l}\text { Dívida fiscal } \\
\text { líquida (10831) }\end{array}$ & 27,98 & 28,89 & 31,46 & 37,64 & 37,01 & 37,94 & 37,52 & 32,85 & 37,41 & 35,06 & 33,42 \\
\hline $\begin{array}{l}\text { Ajuste de } \\
\text { privatização (10826) }\end{array}$ & n.d. & $(0,09)$ & $(1,76)$ & $(3,02)$ & $(3,35)$ & $(4,78)$ & $(4,40)$ & $(3,65)$ & $(3,65)$ & $(2,84)$ & $(2,71)$ \\
\hline $\begin{array}{l}\text { Ajuste patrimonial } \\
(10827)\end{array}$ & n.d. & 1,74 & 1,55 & 3,05 & 3,81 & 4,28 & 5,74 & 5,31 & 5,35 & 4,32 & 4,07 \\
\hline $\begin{array}{l}\text { Ajuste metodológico } \\
(10828+10830)\end{array}$ & n.d. & 0,18 & 0,58 & 1,26 & 7,06 & 8,11 & 9,58 & 15,96 & 13,25 & 8,37 & 8,34 \\
\hline Total & 27,98 & 30,72 & 31,83 & 38,94 & 44,53 & 45,54 & 48,44 & 50,46 & 52,36 & 44,91 & 43,13 \\
\hline
\end{tabular}

(*) posição até agosto; nos demais anos, posição de 31 de dezembro.

Fonte: Bacen/Depec (2007, séries temporais identificadas pelo código). 
Sérgio Wulff Gobetti

\section{2 $\mathrm{O}$ ajuste fiscal e as novas rotinas das estatais}

Do ponto de vista jurídico, as empresas estatais federais são definidas como "as sociedades anônimas de economia mista e as suas subsidiárias e controladas, as empresas públicas, bem como as demais empresas em que a União, direta ou indiretamente, detenha a maioria do capital social com direito a voto" (Dest, 2006, p. 13). Por serem dotadas de personalidade jurídica de direito privado, estão sujeitas à Lei das Sociedades Anônimas no que se refere aos aspectos constitutivos, organizacionais e de relacionamento com o mercado.

Para fins de controle orçamentário, entretanto, as estatais federais são divididas em dois grupos: (1) as que custeiam suas atividades com recursos próprios ou de mercado, e (2) as que dependem de recursos do orçamento fiscal e da seguridade social para pagar parte ou totalidade de seus gastos correntes.

O primeiro grupamento tem sua previsão de gastos inserida no Programa de Dispêndios Globais (PDG), monitorado pelo Dest, e seus gastos com aquisição e manutenção de bens do Ativo Imobilizado detalhados no Orçamento de Investimentos (OI), que é uma das peças do Orçamento Geral da União (OGU). Já o segundo grupo de empresas dependentes tem todas as suas despesas integradas ao OGU e controladas pela Secretaria de Orçamento Federal (SOF), uma outra unidade do Ministério do Planejamento.

Em 2006, o universo de estatais somava 134 unidades: 97 empresas do grupo (1), sendo 75 do setor produtivo (SPE) e 22 do setor financeiro (IF); 17 empresas dependentes do grupo (2); e outras 20 empresas que atuam no exterior e, por isso, não integram o PDG, somente o OI, tendo seus investimentos inseridos no OGU apenas por mera formalidade.

Dessas empresas instaladas no exterior, a Agência Viena e a BB Securities Limited integram o Grupo Banco do Brasil e as 18 seguintes integram o Grupo Petrobras. Note-se ainda que as empresas integrantes do PDG não estão submetidas às disposições da Lei de Responsabilidade Fiscal (LRF), por não receberem recursos do Tesouro Nacional para pagamento de despesas com pessoal ou custeio, mas "são instadas a oferecer sua contribuição para o resultado primário das contas públicas" (Dest, 2006, p. 14), já que fazem parte do conjunto de agentes responsáveis pelo cumprimento das metas fiscais definidas pela LDO.

Por isso, todo o processo de definição do PDG, tanto na fase de proposição pelas empresas quanto no momento de análise e consolidação no âmbito da Dest, é pautado em parâmetros estabelecidos pela equipe econômica e compatibilizado com as metas de superávit primário do setor público. A inclusão das estatais na apuração da Necessidade de Financiamento do Setor Público (NFSP) é, como lembra Biasoto Jr. (2006, p. 198), "uma criação recente, universalizada pelo FMI para os países menos desenvolvidos e derivada de uma postura política decorrente do chamado Consenso de Washington". 
No caso brasileiro, a meta de superávit primário das estatais não inclui o setor financeiro e é sempre definida previamente à elaboração e aprovação do PDG, de modo que o programa de dispêndios seja perfeitamente adequado à NFSP. No ano de execução do programa, da mesma forma, as despesas são periodicamente avaliadas pela Dest e, em casos de necessidade decorrente de contingências relacionadas a alterações nas premissas macroeconômicas, as empresas podem ser chamadas para uma nova revisão de suas metas.

\subsection{A contribuição das estatais para o superávit primário}

Nesta seção vamos apresentar uma mensuração da efetiva contribuição das empresas estatais para o equilíbrio fiscal do setor público, que não se restringe aos valores de superávit primário reportados pelo Banco Central e reproduzidos na Tabela 2 (abaixo). Por esses dados, a contribuição das estatais oscilaria em torno de $0,76 \%$ do PIB desde 2003, com destaque para as empresas federais $(0,58 \%$ do PIB), frente a um superávit médio do setor público de $4,13 \%$.

A apuração do superávit primário do setor público, incluindo as estatais, é feita por duas metodologias distintas: acima e abaixo da linha. O conceito "abaixo da linha", utilizado pelo Banco Central, captura o resultado pela variação de estoques de dívidas e disponibilidades em dois períodos de tempo, excluindo os efeitos dos juros incidentes sobre esses montantes no mesmo período. Já o conceito "acima da linha", aplicado separadamente em cada esfera do setor público pelo respectivo órgão de controle - como o Dest para as estatais federais mensura o resultado primário pela diferença entre o fluxo de receitas e despesas, excluindo as de caráter financeiro.

Tabela 2

Resultado primário das estatais e do setor público (\% PIB)

\begin{tabular}{l|c|r|r|r|c}
\hline Ano & Federais (F) & Estaduais (E) & Municipais (M) & F+E+M & Setor Público \\
\hline 1997 & 0,24 & $-0,17$ & $-0,02$ & 0,05 & $-0,88$ \\
\hline 1998 & $-0,23$ & $-0,06$ & $-0,03$ & $-0,33$ & 0,01 \\
\hline 1999 & 0,60 & 0,01 & $-0,02$ & 0,59 & 2,92 \\
\hline 2000 & 0,86 & 0,13 & 0 & 0,99 & 3,24 \\
\hline 2001 & 0,58 & 0,27 & 0,01 & 0,86 & 3,35 \\
\hline 2002 & 0,43 & 0,24 & 0 & 0,67 & 3,55 \\
\hline 2003 & 0,56 & 0,22 & 0,01 & 0,80 & 3,89 \\
\hline 2004 & 0,46 & 0,12 & 0 & 0,58 & 4,18 \\
\hline 2005 & 0,61 & 0,15 & 0 & 0,77 & 4,35 \\
\hline 2006 & 0,58 & 0,24 & 0 & 0,82 & 3,88 \\
\hline $2007 *$ & 0,68 & 0,15 & 0 & 0,83 & 4,37 \\
\hline
\end{tabular}

(*) últimos 12 meses, até junho.

Fonte: NFSP “abaixo da linha”, sem desvalorização cambial (BC/Depec). 
Sérgio Wulff Gobetti

Tabela 3

Diferenças na apuração do resultado primário da esfera federal (R \$ milhões)

\begin{tabular}{c|c|c|c|c|c|c|c|c}
\hline \multirow{2}{*}{ Ano } & \multicolumn{2}{|c|}{ Acima da linha } & \multicolumn{2}{c|}{ Abaixo da linha } & \multicolumn{2}{c|}{ GC: (c) - (a) } & \multicolumn{2}{c}{ Estatais: (d) - (b) } \\
\cline { 2 - 9 } & GC (a) & Estatais (b) & GC (c) & $\begin{array}{c}\text { Estatais } \\
\text { (d) }\end{array}$ & Discrepância & Itaipu* & Itaipu* & Discrepância \\
\hline 2000 & 20.982 & 12.529 & 20.431 & 10.174 & $(552)$ & & & $(2.355)$ \\
\hline 2001 & 21.737 & 11.887 & 21.980 & 7.571 & 243 & & & $(4.316)$ \\
\hline 2002 & 31.713 & 11.021 & 31.919 & 6.319 & 206 & & & $(4.701)$ \\
\hline 2003 & 39.289 & 11.176 & 38.744 & 9.597 & $(545)$ & & & $(1.579)$ \\
\hline 2004 & 49.369 & 13.774 & 52.385 & 8.937 & 908 & 2.108 & $(2.108)$ & $(2.728)$ \\
\hline 2005 & 52.817 & 17.269 & 55.741 & 13.178 & 525 & 2.400 & $(2.400)$ & $(1.691)$ \\
\hline 2006 & 48.889 & 16.215 & 51.352 & 13.544 & $(128)$ & 2.591 & $(2.591)$ & $(81)$ \\
\hline
\end{tabular}

(*) Recursos transitórios referentes à amortização de contratos de Itaipu com o Tesouro Nacional, só apurados a partir de 2004.

Fonte: STN/DEST (acima da linha) e BC/DEPEC (abaixo da linha).

Em tese, como todo eventual excesso de despesas sobre receitas deve ser financiado por endividamento ou "queima" de disponibilidades, as duas metodologias devem convergir para um resultado muito parecido, senão igual. As eventuais diferenças são classificadas como discrepâncias e se devem a imperfeições em uma ou ambas as formas de apuração. No caso brasileiro, entretanto, a comparação entre os resultados apurados para a esfera federal governo central e estatais - pelo BC e pela STN/Dest revela algumas outras diferenças que merecem destaque, como pode ser observado na Tabela 3 (acima).

Uma dessas diferenças entre a apuração do resultado acima e abaixo da linha para o governo central (GC) se deve, por exemplo, à amortização dos contratos de Itaipu com o Tesouro Nacional. Para a STN, essa receita - por seu caráter financeiro - não entra no cálculo do superávit primário do governo central; da mesma forma, para o Dest, a despesa de Itaipu é financeira e também não afeta negativamente seu resultado. Na prática, o pagamento de Itaipu para o Tesouro deveria ser registrado pelo BC no critério "abaixo da linha" como uma redução de endividamento da empresa binacional, mas, como a operação não se dá por intermédio do sistema bancário, o que se detecta é apenas uma transferência de disponibilidades em favor do Tesouro.

Assim, o BC sempre superestima o superávit primário do GC e subestima o das estatais por uma magnitude equivalente às transferências de Itaipu ao Tesouro, que têm oscilado em torno de $\mathrm{R} \$ 2,5$ bilhões nos últimos três anos, quando passaram, então, a ser explicitadas na programação financeira do governo federal numa linha de "Ajuste Metodológico". Essa diferença não afeta, entretanto, o resultado global do setor público. 
Por decisão do Tribunal de Contas da União (TCU), os órgãos de controle das estatais não têm competência para fixar os gastos de Itaipu, por se tratar de uma empresa binacional, mas a Dest sempre efetua a programação das empresas da União com um valor indicativo de previsão de seu superávit primário. Os balanços publicados pelo Dest a cada ano também incluem Itaipu na consolidação da Necessidade de Financiamento Líquido (Nefil).

A última coluna da Tabela 3 revela que, além da diferença devida às transferências de Itaipu para o Tesouro, existe uma discrepância adicional entre o resultado das estatais apurado pelo Dest e pelo BC, resultante possivelmente das metodologias diferenciadas e também do fato de as planilhas do PDG expressarem a execução das despesas pelo critério de competência.

Esse valor a mais de superávit das estatais contabilizado pelo Dest não entra no resultado consolidado da NFSP apurado pelo BC e, por isso, não será considerado na nossa análise, até porque o objetivo, aqui, é investigar quanto desse "resultado abaixo da linha" pode ser caracterizado como uma contribuição efetiva das estatais. Uma primeira parcela de contribuição, como já destacamos, pode ser mensurada pelo resultado primário atribuído às estatais (incluindo estaduais e municipais), que corresponde ao valor reportado pelo $\mathrm{BC}$ adicionado às transferências de Itaipu ao Tesouro que aparecem no resultado do GC.

$\mathrm{Na}$ análise que nos propomos, entretanto, é possível identificar uma segunda fonte de contribuição das estatais para o resultado primário, configurada pelos pagamentos que as estatais realizam ao Tesouro a título de dividendos e compensações financeiras, notadamente royalties e Participação Especial do Petróleo (PE). Cerca de $60 \%$ desses royalties e PEs são transferidos a Estados e Municípios (como trataremos na seção 3), o que não interfere no objetivo de nossa análise de mensurar quanto do superávit primário do setor público pode ser explicado pela contribuição das estatais.

Poderíamos inclusive ir além dos dividendos e compensações financeiras, computando também outros pagamentos de tributos e encargos parafiscais executados pelas estatais, mas vamos nos restringir nesse momento apenas aos itens mencionados. A Tabela 4 (a seguir) reproduz os valores informados pela STN a título de dividendos, isto é, compensações financeiras do setor de petróleo que são pagas pelo Grupo Petrobras, e os royalties de recursos hídricos pagos pelo sistema Eletrobrás e por Itaipu, extraídos do PDG.

A consolidação dos dados coletados nos relatórios da STN mostra, categoricamente, que a contribuição das estatais (incluindo agora as estaduais e municipais) para o superávit primário do setor público é crescente e atingiu a cifra de 54,3\% em 2006. Ou seja, as empresas controladas pelos governos estão respondendo por mais da metade do esforço necessário ao cumprimento das metas 
de ajuste fiscal, o que revela um papel decisivo para as mesmas no atual quadro macroeconômico.

É verdade que, mesmo se estivessem sob controle privado, tais empresas continuariam pagando as compensações financeiras relativas aos royalties e PEs, mas o mesmo não ocorreria, por exemplo, com os dividendos pagos à União. É importante frisar que não estão computados nessa tabela os dividendos das empresas estaduais e municipais, como também não estão registrados eventuais transferências do Tesouro às estatais, que são atualmente desprezíveis (como podemos detectar pela análise do PDG). Os relatórios de consolidação de usos e fontes disponibilizados pelo Dest, por exemplo, mostram que desde 1999 os subsídios do Tesouro às estatais são desprezíveis, totalizando pouco mais de R $\$ 1$ milhão - muito pouco se comparados com o que ocorria nas décadas de 1970 e 80.

O mais importante da análise realizada é sua demonstração de que, somente no período considerado, de 1999 a 2006, a contribuição das estatais para o ajuste fiscal totaliza, em valores atualizados pelo deflator do PIB, cerca de R \$ 254 bilhões ou US\$ 90 bilhões, pouco mais do que a receita obtida entre 1991 e 2002 com o programa de privatização. Enquanto a receita proveniente das privatizações é "once for all", a contribuição das estatais para o ajuste fiscal pode ser mantida ou ajustada pelo governo de acordo com as necessidades.

Tabela 4

Fontes de contribuição das estatais para resultado primário ( $\mathrm{R}$ milhões):

\begin{tabular}{l|c|c|c|c|c|c|c}
\hline Ano & $\begin{array}{c}\text { Superávit } \\
\text { Estatais* } \\
(\mathrm{A})\end{array}$ & $\begin{array}{c}\text { Dividendos } \\
(\mathrm{C})\end{array}$ & $\begin{array}{c}\text { Rendas } \\
\text { Petróleo } \\
(\mathrm{D})\end{array}$ & $\begin{array}{c}\text { Rendas } \\
\text { Hídricos } \\
(\mathrm{E})\end{array}$ & $\begin{array}{c}\text { Soma } \\
(\mathrm{F})\end{array}$ & $\begin{array}{c}\text { Superávit } \\
\text { Setor } \\
\text { Público (G) }\end{array}$ & F/G \\
\hline 1999 & 6.310 & 1.210 & 286 & 474 & 8.280 & 31.087 & $26,6 \%$ \\
\hline 2000 & 11.700 & 1.419 & 2.975 & 511 & 16.606 & 38.157 & $43,5 \%$ \\
\hline 2001 & 11.204 & 2.483 & 3.982 & 638 & 18.307 & 43.655 & $41,9 \%$ \\
\hline 2002 & 9.838 & 2.742 & 5.846 & 831 & 19.257 & 52.390 & $36,8 \%$ \\
\hline 2003 & 13.608 & 3.839 & 9.428 & 774 & 27.649 & 66.173 & $41,8 \%$ \\
\hline 2004 & 13.354 & 4.310 & 10.482 & 844 & 28.990 & 81.112 & $35,7 \%$ \\
\hline 2005 & 18.840 & 4.854 & 13.258 & 869 & 37.820 & 93.505 & $40,4 \%$ \\
\hline 2006 & 21.668 & 9.719 & 16.604 & 960 & 48.950 & 90.144 & $54,3 \%$ \\
\hline
\end{tabular}

(*) Inclui pagamentos de Itaipu ao Tesouro como redução de endividamento das estatais.

Fonte: Bacen/STN/Dest.

\subsection{A contribuição das estatais para a arrecadação tributária}

$\mathrm{Na}$ seção anterior, mensuramos a contribuição das estatais para o equilíbrio fiscal a partir do superávit primário gerado pelas empresas e das transferências fiscais realizadas ao Tesouro, como os dividendos e os royalties, mostrando um peso crescente desses recursos no resultado de todo o setor público. 
Nesta breve seção, mostraremos que os demais recursos tributários originados das estatais federais também estão assumindo um peso crescente na composição da arrecadação das três esferas de governo.

No PDG, podemos identificar duas rubricas de despesa associadas a pagamentos de tributos e obrigações de caráter compulsório: (i) "Tributos e Encargos Parafiscais", que reúne tributos vinculados à receita (IPI, ICMS, ISS, PIS/Pasep, Cofins e Cide), a resultados (IRPJ e CSLL) e esporádicos (IPTU, ITBI, taxas e contribuições); (ii) "Encargos Sociais", um subgrupo das despesas de pessoal constituído por contribuições previdenciárias, FGTS, sistema S e alguns itens não tributários, como $13^{\circ}$ salário, férias e aviso prévio.

Pela impossibilidade de excluir esses últimos itens associados às obrigações trabalhistas do grupo (ii), nos restringimos a comparar o grupo (i) com os valores totais arrecadados pela União, Estados e Municípios nos respectivos tributos. Esses dados foram coletados respectivamente na STN, Confaz e Finbra e confrontados com os números do PDG.

A Tabela 5 (a seguir) indica que as receitas provenientes das estatais já representam cerca de $14 \%$ das receitas de impostos e contribuições do país - quase o dobro da participação de 7,7\% registrada em 1999. Em 2006, as estatais repassaram aos cofres públicos $\mathrm{R} \$ 81,6$ bilhões em tributos, sem contar royalties em geral ( $\mathrm{R} \$ 17,5$ bilhões), dividendos ( $\mathrm{R} \$ 9,7$ bilhões) e encargos sociais, majoritariamente contribuição previdenciária e FGTS (R \$ 9,5 bilhões).

Ou seja, verificamos que a evolução crescente dos "Tributos e Encargos Parafiscais" das estatais constitui outro importante canal de contribuição para o equilíbrio fiscal do setor público, que estava ausente no período anterior. Da condição de bode expiatório da crise fiscal do setor público, nos anos 1980, as estatais transformaram-se hoje em importantes protagonistas para a sustentação deste setor.

Em termos relativos, os tributos pagos pelas estatais passaram de $1,7 \%$ do PIB em 1999 para cerca de 3,6\% do PIB entre 2002 e 2006, configurando uma outra fonte de explicação também para o aumento da carga tributária. No mesmo período, as receitas tributárias da Tabela 5 cresceram de 21,5\% do PIB (ou 28,9\% com encargos sociais) para $26,1 \%$ (ou $34,6 \%$ com encargos), como vemos no Gráfico 2 (a seguir). Logo, podemos depreender disso que cerca de $40 \%$ do aumento da carga tributária entre 1999 e 2006 foi suportado pelas empresas estatais federais. 
Tabela 5

Receitas tributárias provenientes das estatais federais (R\$ milhões)

\begin{tabular}{l|r|r|r|r|r|r|r|r}
\hline Descrição & 1999 & 2000 & 2001 & 2002 & 2003 & 2004 & 2005 & 2006 \\
\hline $\begin{array}{c}\text { Rec. Tributárias } \\
\text { (A) }\end{array}$ & 228.913 & 266.856 & 308.758 & 367.276 & 410.704 & 479.525 & 556.798 & 605.351 \\
\hline $\begin{array}{c}\text { Origem: Estatais } \\
\text { (B) }\end{array}$ & 17.718 & 27.959 & 38.609 & 52.683 & 60.727 & 70.870 & 77.554 & 81.601 \\
\hline SPE (B1) & 16.560 & 25.214 & 35.528 & 46.889 & 54.608 & 62.718 & 68.814 & 75.955 \\
\hline $\begin{array}{c}\text { Financeiras } \\
(B 2)\end{array}$ & 1.158 & 2.744 & 3.081 & 5.793 & 6.118 & 8.152 & 8.740 & 5.646 \\
\hline B/A & $7,7 \%$ & $10,5 \%$ & $12,5 \%$ & $14,3 \%$ & $14,8 \%$ & $14,8 \%$ & $13,9 \%$ & $13,5 \%$ \\
\hline B1/A & $7,2 \%$ & $9,4 \%$ & $11,5 \%$ & $12,8 \%$ & $13,3 \%$ & $13,1 \%$ & $12,4 \%$ & $12,5 \%$ \\
\hline B2/A & $0,5 \%$ & $1,0 \%$ & $1,0 \%$ & $1,6 \%$ & $1,5 \%$ & $1,7 \%$ & $1,6 \%$ & $0,9 \%$ \\
\hline
\end{tabular}

(*) Receitas tributárias (estimada para os três níveis de governo, excluindo royalties e folha); Estatais: Tributos e Encargos Parafiscais.

Fonte: Elaboração própria (a partir de dados da STN, SRF, Confaz e Dest).

Gráfico 2

Receita Tributária, excluindo contribuições sobre a folha e royalties, de acordo com a origem de pagamento (1999-2006)

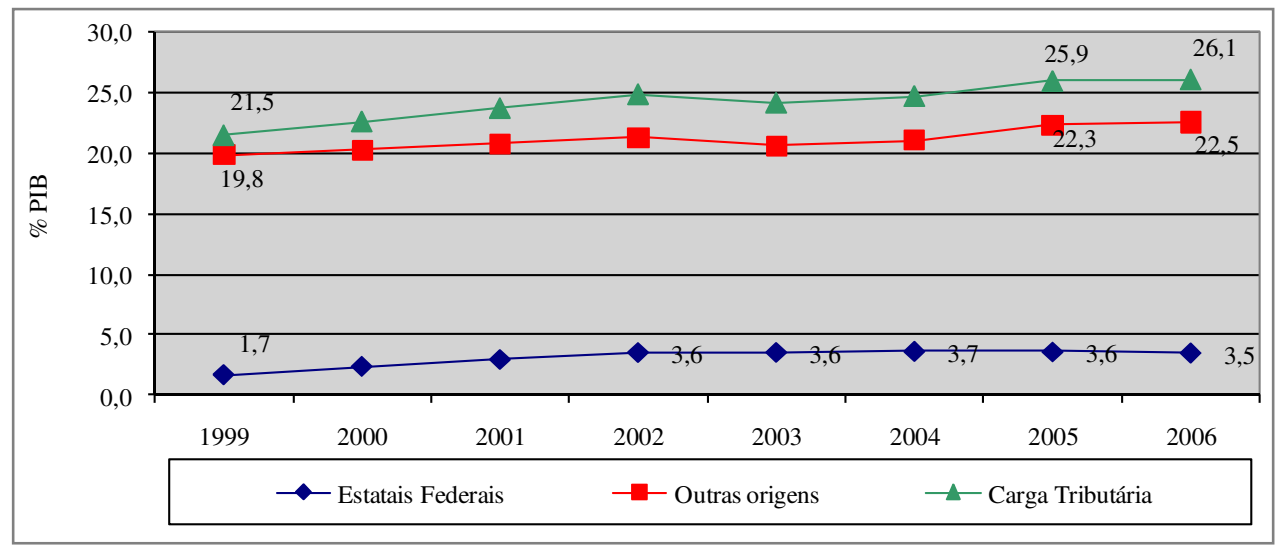

Fonte: Elaboração própria (a partir da Tabela 5).

Se incluíssemos os royalties na comparação, o peso do aumento da tributação sobre as estatais seria ainda maior, dado que essa foi a receita governamental que mais cresceu nos últimos anos e, como já assinalamos, está fortemente concentrada no setor estatal. É claro que grande parte dos impostos indiretos é repassada ao consumidor, principalmente em setores como o de combustíveis, dominado pela Petrobras, em que a demanda é inelástica aos preços, mas uma parcela importante de tributação também tem incidido sobre os lucros das empresas. Isso ajuda a compreender melhor porque a carga tributária brasileira 
continua crescendo nos últimos dois anos mesmo sem mudanças na legislação tributária e nas alíquotas.

A Tabela 6 (abaixo), por exemplo, apresenta dados da Secretaria da Receita Federal para a arrecadação bruta do IRPJ e da CSLL, dois tributos que incidem sobre o lucro das empresas. Selecionando por código de CNAE aquelas atividades principais do setor estatal (petróleo e energia), verificamos que a participação relativa das mesmas, na receita dos dois impostos federais, cresceu de 12,3\% em 2000 para 19,3\% em 2006. Ou seja, mais um claro indício de que a contribuição das estatais para o crescimento da carga tributária tem sido, em termos proporcionais, superior ao das empresas do setor privado.

Esses resultados apontam para a necessidade de um estudo mais detalhado sobre o aumento da carga tributária e sua tendência de se concentrar em setores de fácil arrecadação e com características monopolísticas ou oligopolísticas, como o petróleo, a eletricidade e as telecomunicações.

Tabela 6

Arrecadação bruta de IRPJ e CSLL (em R \$ milhões):

\begin{tabular}{l|r|r|r|r|r|r|r}
\hline Atividade econômica & \multicolumn{1}{|c|}{2000} & \multicolumn{1}{c|}{2001} & \multicolumn{1}{c|}{2002} & \multicolumn{1}{c}{2003} & 2004 & \multicolumn{1}{c}{2005} & \multicolumn{1}{c}{2006} \\
\hline Petróleo e biocombustíveis & 2.555 & 2.216 & 2.439 & 6.897 & 5.676 & 9.816 & 11.033 \\
\hline Eletricidade, gás e UP's & 738 & 436 & 1.172 & 1.565 & 2.797 & 4.280 & 4.822 \\
\hline Sub-total (A) & 3.293 & 2.652 & 3.611 & 8.461 & 8.473 & 14.096 & 15.855 \\
\hline Total (B) & 26.730 & 26.176 & 46.934 & 49.192 & 56.425 & 74.651 & 81.940 \\
\hline A/B & $12,3 \%$ & $10,1 \%$ & $7,7 \%$ & $17,2 \%$ & $15,0 \%$ & $18,9 \%$ & $19,3 \%$ \\
\hline
\end{tabular}

Fonte: SRF (relatório por CNAE).

\section{Gestão das estatais: uma análise dos investimentos e demais despesas}

$\mathrm{Na}$ seção anterior, analisamos o papel desempenhado pelas estatais para o equilíbrio fiscal do setor público a partir unicamente da ótica de sua contribuição direta ou indireta ao superávit primário. Nesta seção, analisamos em mais detalhes os resultados financeiros e os gastos das estatais, com o objetivo de identificar, em primeiro lugar, os principais traços distintivos do novo padrão de gestão das empresas sob controle do governo.

Antes disso, porém, é importante lembrar a ressalva apresentada na introdução: os gastos das estatais, pela natureza mercantil de suas atividades, "não podem ser analisados do mesmo modo como o são os dispêndios de natureza fiscal incluídos no Orçamento Geral da União" (Braga, 1984). Dito de outra forma: enquanto o governo necessita ampliar a tributação para fornecer mais serviços públicos, as empresas precisam gastar mais para ampliar a produção e serviços e obter receita e lucro maiores. 
Dessa forma, o eventual aumento das despesas nas estatais não representa necessariamente um caso de "gastança", sendo necessário uma análise mais aprofundada para identificar as tendências por trás dos números do PDG. Por outro lado, os investimentos das estatais merecem atenção à parte, pela importância que possuem para o crescimento econômico (o que faremos dedicando uma seção à sua análise, mais à frente).

\subsection{O novo padrão de gastos e a expansão das empresas}

Os relatórios anuais elaborados pela Dest com as informações da execução orçamentária das estatais reúnem os dados de todas as empresas exceto aquelas dependentes, custeadas com recursos do OGU. Os Anexos apresentam os dados completos da série histórica do PDG entre 1995 e 2006, em valores monetários constantes, que estão sintetizados na Tabela 7 (abaixo).

Tabela 7

Evolução dos gastos das Estatais federais (em R \$ milhões, constantes):

\begin{tabular}{l|c|c|c|c}
\hline Consolidado (s/dependentes) & 1995 & 1999 & 2002 & 2006 \\
\hline Pessoal e Encargos Sociais & 46.806 & 32.967 & 25.452 & 30.234 \\
\hline Juros e Outros & 89.032 & 81.559 & 103.164 & 57.652 \\
\hline ODC & 93.268 & 100.422 & 213.178 & 230.583 \\
\hline Materiais e Produtos & 29.462 & 27.389 & 63.541 & 64.761 \\
\hline Locação Equipamentos & 249 & 215 & 140 & 230 \\
\hline Serviços Terceiros & 17.846 & 15.964 & 22.191 & 33.722 \\
\hline Utilidades e Serviços & 2.309 & 1.810 & 2.531 & 2.860 \\
\hline Tributos e Encargos Parafiscais & 30.987 & 31.207 & 72.544 & 81.601 \\
\hline Demais Dispêndios Correntes* & 12.416 & 23.836 & 52.232 & 47.408 \\
\hline Investimentos & 22.459 & 16.227 & 26.223 & 33.504 \\
\hline Inversões Financeiras & 1.856 & 12.974 & 12.162 & 4.746 \\
\hline Amortizações & 18.083 & 40.879 & 35.952 & 34.378 \\
\hline Outros Dispêndios Capital** & 3.906 & 17.265 & 25.266 & 24.552 \\
\hline Número Empregados*** & 531.544 & 339.120 & 340.776 & 398.686 \\
\hline Despesa Média/Empregado**** & $\mathrm{R} \$ 6.774$ & $\mathrm{R} \$ 7.478$ & $\mathrm{R} \$ 5.745$ & $\mathrm{R} \$ 5.833$ \\
\hline (*) Inclui pagamento de royalties. & $(* * *)$ Exclui empresas dependentes do OGU. & \\
(**) Inclui dividendos. & $(* * * *)$ Custo médio por empregado, incluindo encargos sociais. \\
Fonte: Elaboração própria (Dados completos: Anexo 1, valores correntes, e Anexo 2, constantes).
\end{tabular}

Como podemos observar, as despesas correntes e as despesas de capital apresentaram inicialmente, com as privatizações, uma queda de valores reais, mas desde o ano de 2000 estão novamente crescendo. Ou seja, as empresas estatais remanescentes estão em clara expansão. Isso fica evidente quando olhamos para os 
investimentos em ativo imobilizado (do qual trataremos especificamente na próxima seção), e para os principais elementos do grupo aqui denominado ODC: os gastos com "Materiais e Produtos" e "Serviços Terceiros", por exemplo, crescem $119,8 \%$ e 89,0\% em termos reais, respectivamente, entre 1995 e 2006.

Evidentemente, trata-se de gastos tipicamente produtivos que, como tais, não podem ser comparados com outros custos, como os de "Utilidades e Serviços", que, por sinal, crescem menos $-23,9 \%$ - no período analisado. Uma análise mais criteriosa da qualidade desses gastos e aferição de eventuais desperdícios exigiria a análise de outros dados quantitativos que não estão disponíveis (e nem estariam ao alcance deste artigo).

De qualquer forma, a análise das Demonstrações Financeiras Consolidadas das Estatais mostra que os resultados das empresas do setor produtivo são cada vez melhores. Para se ter uma ideia, a receita líquida do SPE em bloco cresceu de $\mathrm{R} \$ 39,87$ bilhões em 1995 para $\mathrm{R}$ \$ 197,03 bilhões em 2006, considerando os valores correntes. No mesmo período, o lucro líquido desse grupo de empresas pulou de $\mathrm{R} \$ 1,66$ bilhão para $\mathrm{R} \$ 27,28$ bilhões, de acordo com os dados da Dest, apresentados de forma ilustrada no Gráfico 3 (abaixo).

Gráfico 3

Resultados financeiros do setor produtivo estatal

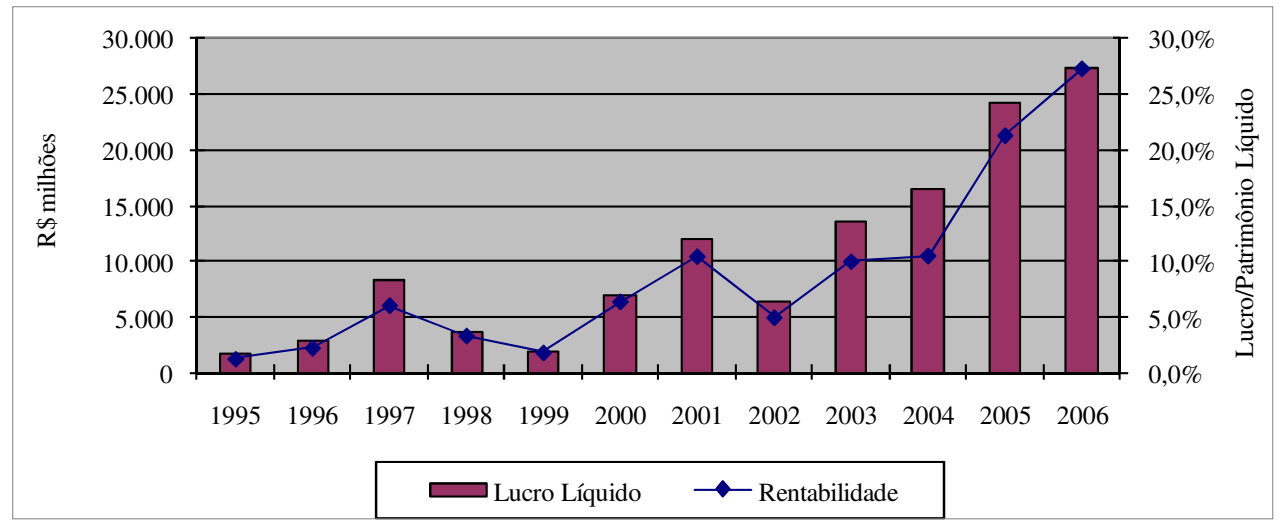

Fonte: Elaboração própria (Origem primária: Dest).

Este gráfico também mostra que a rentabilidade, medida em proporção do patrimônio líquido, cresce de 1,8\% em 1999, logo após as privatizações, para $27,2 \%$ em 2006. Ou seja, mesmo perdendo um considerável número de empresas, o SPE vem crescendo - em receitas e gastos - e gerando lucros cada vez mais significativos, que se revertem em dividendos, incluídos no grupo "Outras Despesas de Capital", e em royalties, no grupo "Demais Dispêndios Correntes" (como analisaremos mais detalhadamente na próxima e última seção). 
Há de se ressaltar, entretanto, que 95\% do lucro obtido pelo SPE em 2006 proveio do grupo Petrobras, e outros $4 \%$ do grupo Eletrobrás, totalizando $99 \%$. Da receita líquida, $80 \%$ são da Petrobras, e $10 \%$ da Eletrobrás. Isso revela que hoje, quando estamos tratando dos resultados das estatais, são os setores de petróleo e energia elétrica que realmente importam e influenciam os indicadores financeiros.

\subsection{As despesas de pessoal}

Os dados sobre a evolução dos gastos com "Pessoal e Encargos Sociais" também são importantes para termos mais claro o panorama da atual gestão das estatais. Ao contrário das outras despesas correntes e dos investimentos, esses gastos também caíram após o período principal das privatizações (1997-1999) e, mesmo tendo voltado a crescer nos anos mais recentes, continuam, em valores reais, mais baixos do que em 1995 .

De acordo com a Tabela 7 apresentada anteriormente, vemos que a despesa global de pessoal das estatais, incluindo SPE e instituições financeiras e excluindo as empresas dependentes, somou R $\$ 30,2$ bilhões em 2006, o que representa $34,5 \%$ a menos do que em 1995, mas 18,8\% a mais do quem em 2002, com valores atualizados pelo deflator do PIB.

Os dados mostram que a redução da despesa ocorreu, principalmente, pela queda do número de empregados - de 531.544 em 1995 para 398.686 em 2006 provocada tanto pela exclusão das empresas privatizadas, quanto pela modernização e enxugamento do quadro de pessoal de outras empresas, notadamente os bancos.

Os Anexos, ao final, contêm os dados para todos os anos da série considerada e mostram que o menor número de empregados foi registrado em 2000 (324.886). Depois disso, portanto, há uma retomada das contratações de trabalhadores, não só no setor produtivo, como também no financeiro. No SPE (excluindo empresas dependentes), o número de empregados passou de 174.604 em 2000 para 228.785 em 2006. Nas instituições financeiras, a expansão foi de 146.826 para 169.901 no mesmo período.

Esse recente movimento de contratações, que acompanha a expansão de algumas atividades do setor produtivo, mas também se manifesta nos bancos, explica porque a folha de pessoal volta a crescer em termos reais, principalmente nos últimos três anos, e indica aparentemente uma opção do novo governo de reforçar a inserção econômica das estatais e compensar as restrições fiscais da administração pública, direta e indireta.

Outra forma de analisarmos as despesas de pessoal é olhando para a evolução do custo médio real por empregado, que também está apresentado na 
Tabela 7. Considerando apenas as empresas do PDG, a média mensal cresceu $1,5 \%$ entre 2002 e 2006 , passando de $\mathrm{R} \$ 5.745$ para $\mathrm{R} \$ 5.833$, mas continua abaixo do pico de R\$ 7.779 registrado em 1998, quando algumas empresas já haviam sido alienadas. O Gráfico 4 (abaixo) mostra como essas médias têm evoluído nos distintos grupos de empresas: financeiras e produtivas, do PDG, e dependentes, do OGU. Podemos verificar como essa média caiu mais acentuadamente no setor financeiro do que no produtivo e que, entre as dependentes, vinha crescendo até 2003, na contramão das demais. Hoje as médias estão todas muito próximas, entre $\mathrm{R} \$ 5,5$ mil e $\mathrm{R} \$ 6$ mil.

Gráfico 4

Despesa média mensal com pessoal das estatais

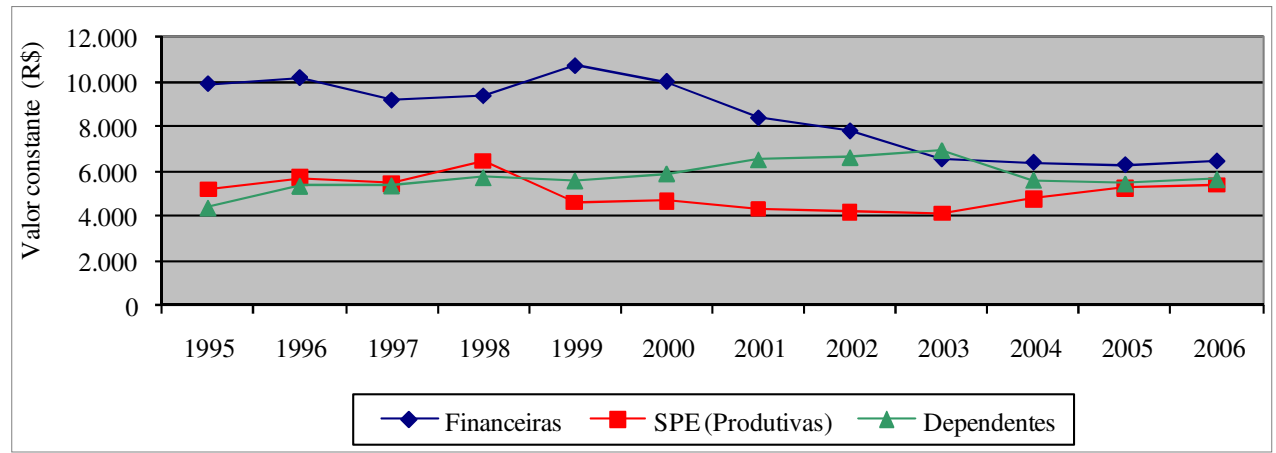

Fonte: Elaboração própria (Origem primária: Dest e Secretaria de Recursos Humanos para dependentes).

\subsection{Os investimentos das estatais e seus impactos econômicos}

Os investimentos das estatais, como já foi assinalado anteriormente, estão crescendo significativamente nos últimos anos. Na Tabela 8 (a seguir), apresentamos os valores dos investimentos que constam de duas diferentes fontes de informação: o Programa de Dispêndios Globais (PDG), que vínhamos usando, e o Orçamento de Investimentos (OI), que é parte integrante do OGU e será utilizado nas análises a partir de agora, por algumas conveniências, como a frequência mensal dos dados disponibilizados pela Dest.

Os valores, como podemos notar, são muito parecidos, divergindo apenas por algumas diferenças de abrangência e de conceito, como a consideração de gastos com arrendamento mercantil no PDG e não no OI. De qualquer forma, por um ou outro critério, verificamos que os investimentos das estatais cresceram, em termos reais, identicamente entre 1999 e 2006 - 106,5\% (PDG) e 106,6\% (OI).

É importante notar, entretanto, que os investimentos das estatais federais foram fundamentais para compensar parcialmente a queda dos investimentos da 
União entre 2003 e 2005, no início do governo Lula, quando a equipe econômica decidiu aprofundar o ajuste fiscal com cortes profundos nos programas de infraestrutura. Os valores dos investimentos da União foram extraídos do estudo de Gobetti (2006), que considera como executados apenas as despesas efetivamente liquidadas, incluindo restos a pagar não-processados. ${ }^{12}$

Em 2003 e 2004, os investimentos da União caíram para níveis duas vezes menores dos que vinham prevalecendo nos anos anteriores, em 2005 se recuperaram parcialmente e, em 2006, voltaram finalmente a se aproximar do pico de 2002. Caso as estatais não tivessem mantido seus investimentos em ascensão no período citado, os efeitos recessivos do aperto fiscal que se manifestaram sobre a economia brasileira talvez fossem maiores.

Essa capacidade de investimento das estatais já era conhecida pela equipe econômica em 2003, quando decidiu aumentar a meta de superávit primário do setor público e contingenciar o Orçamento da União, dando maior margem de manobra para a política fiscal. Enquanto os investimentos da União (aplicações diretas e transferências) declinaram enormemente de $\mathrm{R} \$ 18,5$ bilhões para $\mathrm{R} \$ 8,5$ bilhões de 2002 para 2003, os das estatais continuaram crescendo sem interrupção, atingindo R \$ 32,8 bilhões em 2006 pelo OI.

Contudo, como verificamos no Gráfico 5 (abaixo), uma crescente parcela dos investimentos das estatais tem sido realizada no Exterior, sem impactar a formação bruta de capital fixo no Brasil (valores destacados sobre o gráfico). Em 2006, por exemplo, $29 \%$ dos investimentos referidos no OI ocorreram em outros países em que as subsidiárias do Grupo Petrobras atuam. Em 1995, esse porcentual era de apenas $1,2 \%$.

Tabela 8

Investimentos federais: Estatais x União (em R \$ milhões deflacionados):

\begin{tabular}{l|c|c|c|c|c|c|c|c}
\hline Fonte & 1999 & 2000 & 2001 & 2002 & 2003 & 2004 & 2005 & 2006 \\
\hline Estatais (PDG) & 16.227 & 17.496 & 20.310 & 26.223 & 26.488 & 30.013 & 29.774 & 33.504 \\
\hline Estatais (OI) & 15.888 & 16.541 & 19.758 & 25.982 & 26.341 & 27.751 & 29.315 & 32.821 \\
\hline União (OGU) & 9.422 & 12.756 & 15.880 & 18.422 & 8.497 & 7.777 & 11.627 & 16.123 \\
\hline Total (OI+OGU) & 25.310 & 29.296 & 35.638 & 44.405 & 34.838 & 35.528 & 40.942 & 48.944 \\
\hline Total/PIB & $1,99 \%$ & $2,05 \%$ & $2,32 \%$ & $2,66 \%$ & $1,96 \%$ & $1,79 \%$ & $1,88 \%$ & $2,11 \%$ \\
\hline
\end{tabular}

Fonte: Elaboração própria (Origem primária: Dest; Gobetti, 2006).

(12) A necessidade de usar esse tipo de metodologia decorre do fato de que o empenho, principalmente para investimentos e em tempos de ajuste fiscal, deixa de ser um bom parâmetro para mensuração da execução orçamentária. A execução, então, é dimensionada pela liquidação das dotações do ano e de RAPs. 
Gráfico 5

Investimentos das estatais federais, por localização (OI)

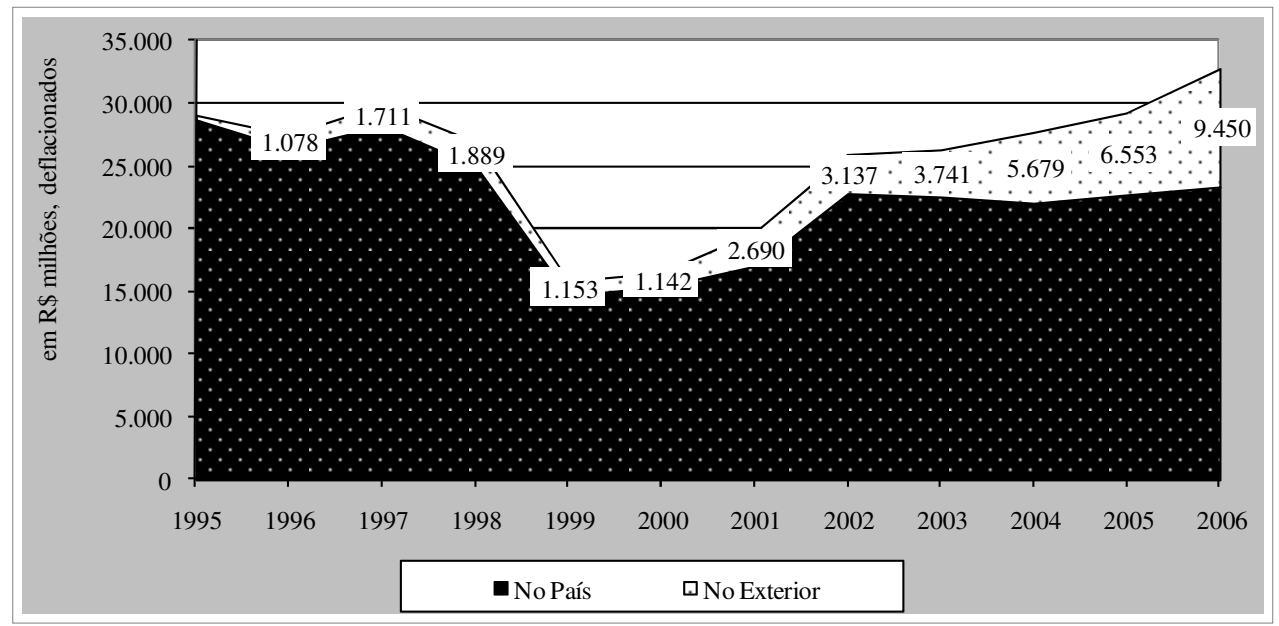

Fonte: Dest (Orçamento de Investimentos).

Segundo Chevarria (2006), isso faz parte de uma nova tendência de investimentos diretos no Exterior de grandes empresas brasileiras - não só estatais - que desenvolveram vantagens específicas, como a tecnologia de exploração e produção de petróleo em águas profundas, por parte da Petrobras, originalmente desenvolvida no Brasil. Esse novo padrão de internacionalização confere uma nova dimensão estratégica para as empresas. De qualquer forma, para nosso objetivo de mensuração da contribuição dos investimentos estatais para a atividade econômica interna, devemos excluir as aplicações no Exterior, seguindo o critério do IBGE para as estimativas da Formação Bruta de Capital Fixo (FBCF).

O IBGE divide suas estimativas para as Contas Nacionais em cinco distintos setores institucionais: empresas não-financeiras, empresas financeiras, administração pública, famílias e instituições sem fins lucrativos a serviço das famílias (ISFLSF). As estatais não integram o setor administração pública, sendo divididas entre empresas financeiras e não-financeiras. $O$ setor administração pública, por outro lado, abrange a atividade governamental nos âmbitos federal, estadual e municipal.

Adaptando a mesma metodologia do IBGE aos dados disponíveis, reestimamos a FBCF da administração pública para o período $2000-2006^{13}$ e, somando aos investimentos das estatais federais do OI (excluindo Exterior), chegamos a proxy do que seria a FBCF do "setor público" (administração pública mais estatais federais), a fim de comparar com os valores globais de FBCF. ${ }^{14}$ Os

(13) Nas contas referência 2000, o IBGE só reestimou a FBCF por setor institucional para o período 1995-1999, existindo uma lacuna de dados para o período 2000-2006.

(14) Para maiores detalhes sobre a metodologia, ver Gobetti (2006). 
resultados apresentados na Tabela 9 (abaixo) confirmam a nossa avaliação inicial: a participação dos investimentos estatais na FBCF total e da FBCF do setor público cresceu entre 2002 e 2004, principalmente em 2003, no auge da crise que se abateu sobre a economia na transição de governo, quando atingiu um pico de $7,2 \%$ (A/D) e $41,7 \%$ (A/C) das respectivas somas. Não temos como estimar qual o real efeito disso sobre a atividade econômica, mas esses números sugerem que os projetos das estatais podem ter cumprido um papel anticíclico, num momento em que setor privado e governos reduziram investimentos em função do aperto fiscal e monetário.

Tabela 9

A participação das estatais na $\mathrm{FBCF}$ (em $\mathrm{R} \$$ milhões, correntes)

\begin{tabular}{l|c|c|c|c|c|c}
\hline Ano & $\begin{array}{c}\text { Estatais } \\
(\mathrm{A})\end{array}$ & $\begin{array}{c}\text { Adm. Pública* } \\
(\mathrm{B})\end{array}$ & $\begin{array}{c}\text { Setor Público } \\
\mathrm{C}=\mathrm{A}+\mathrm{B}\end{array}$ & $\begin{array}{c}\text { FBCF IBGE } \\
(\mathrm{D})\end{array}$ & A/C & A/D \\
\hline 1995 & 11.446 & 15.955 & 27.401 & 129.297 & $41,8 \%$ & $8,9 \%$ \\
\hline 1996 & 12.338 & 17.054 & 29.392 & 142.382 & $42,0 \%$ & $8,7 \%$ \\
\hline 1997 & 14.175 & 16.231 & 30.406 & 163.134 & $46,6 \%$ & $8,7 \%$ \\
\hline 1998 & 13.124 & 23.665 & 36.788 & 166.174 & $35,7 \%$ & $7,9 \%$ \\
\hline 1999 & 8.366 & 15.274 & 23.639 & 166.746 & $35,4 \%$ & $5,0 \%$ \\
\hline 2000 & 9.283 & 21.124 & 30.406 & 198.151 & $30,5 \%$ & $4,7 \%$ \\
\hline 2001 & 11.212 & 24.403 & 35.615 & 221.772 & $31,5 \%$ & $5,1 \%$ \\
\hline 2002 & 16.591 & 32.520 & 49.111 & 242.162 & $33,8 \%$ & $6,9 \%$ \\
\hline 2003 & 18.665 & 26.049 & 44.714 & 259.714 & $41,7 \%$ & $7,2 \%$ \\
\hline 2004 & 19.695 & 31.520 & 51.215 & 312.516 & $38,5 \%$ & $6,3 \%$ \\
\hline 2005 & 21.827 & 35.133 & 56.960 & 349.463 & $38,3 \%$ & $6,2 \%$ \\
\hline 2006 & 23.371 & 46.103 & 69.474 & 390.134 & $33,6 \%$ & $6,0 \%$ \\
\hline
\end{tabular}

(*) União, Estados e Municípios

Fonte: Elaboração própria (Origem primária: IBGE; Dest; Gobetti, 2006).

\section{Conclusões}

Este artigo fez uma análise histórica e empírica de algumas transformações importantes na gestão das empresas estatais e na sua forma de inserção na economia durante os últimos 20 anos, buscando ressaltar principalmente o seu papel para o equilíbrio fiscal e macroeconômico. De vilãs da crise fiscal dos anos 1980, por terem sido usadas pela ditadura militar para captar recursos no Exterior e dar vazão ao mercado de "euromoedas" no início da década de 1970, as empresas estatais federais sobreviveram ao processo de privatização dos anos 1990 e, no período recente, conforme demonstramos, passaram a oferecer uma contribuição efetiva, estimada em mais de 50\%, para o superávit primário do setor público. 
Entre 1999 e 2006, por exemplo, a contribuição direta e indireta das estatais para o superávit primário totalizou $\mathrm{R} \$ 254$ bilhões em valores atualizados pelo deflator do PIB, mais do que toda a receita proveniente da alienação das estatais entre 1991 e 2002. Ou seja, mostramos como o verdadeiro ganho fiscal decorrente da privatização, previsto por inúmeros economistas durante o processo, foi proporcionado pelo fortalecimento e reorganização das estatais remanescentes, com destaque para a Petrobras.

Os ganhos do setor público decorrentes dos dividendos e royalties pagos pelas estatais têm sido cada vez mais significativos, assim como os decorrentes dos tributos e encargos fiscais. Estimamos que a participação das estatais nas receitas tributárias da União, estados e municípios tenha crescido de 7,7\% em 1999 para cerca de $14 \%$ nos anos recentes, respondendo por aproximadamente $40 \%$ do aumento da carga tributária no período.

Além disso, o artigo mostrou como a expansão das estatais, expressa em mais gastos, mais investimentos e mais receitas, têm proporcionado simultaneamente melhores resultados financeiros para as empresas, com uma rentabilidade de $27,2 \%$ do patrimônio líquido em 2006. No caso dos investimentos, em particular, há evidências empíricas de que os projetos executados pelas estatais no Brasil - ao serem mantidos em aceleração durante os recentes anos de retração econômica - contribuíram para compensar o aperto fiscal e monetário promovido pelo governo federal, sobretudo em 2003.

Por tudo isso, concluímos que a situação fiscal e macroeconômica do Brasil seria outra, pior, se não fosse a importante atuação das empresas estatais, contribuindo para o equilíbrio fiscal e mantendo seus investimentos em alta.

\section{Referências bibliográficas}

BACEN. Sistema Gerenciador de Séries Temporais (SGST). Finanças públicas. Disponível em: <www.bcb.gov.br>. Brasília: Banco Central, 2007.

BIASOTO Jr., G. A polêmica sobre o déficit público e a sustentabilidade da política fiscal. In: PINTO, Márcio P. A.; BIASOTO JR., Geraldo (Org.). Política fiscal e desenvolvimento no Brasil. Campinas: IE/Unicamp, 2006.

BIELSCHOWSKY, R.; MUSSI, C. O pensamento desenvolvimentista no Brasil: 19301964 e anotações sobre 1964-2005. Texto preparado para o Seminário "Brasil-Chile: Uma Mirada Hacia América Latina y sus Perspectivas". Santiago de Chile, jul. 2005.

BNDES. Relatório de Atividades 2005: Programa Nacional de Desestatização. Estudos e Publicações. Busca por tema: privatizações. Rio de Janeiro: BNDES, 2005. Disponível em: $<$ www.bndes.gov.br $>$

BRAGA, J. C. Os orçamentos estatais e a política econômica. In: BELLUZZO, L. G.; COUTINHO, R. (Org.). Desenvolvimento capitalista no Brasil: ensaios sobre a crise. São Paulo: Editora Brasiliense, 1984. 
Sérgio Wulff Gobetti

CARDOSO DE MELLO, J. M. O capitalismo tardio. São Paulo: Brasiliense, 1982.

CASTRO, A. B.; SOUZA, F. E. P. A economia brasileira em marcha forçada. Rio de Janeiro: Paz e Terra, 1985.

CHEVARRIA, D. O investimento externo da Petrobras: uma análise com base em vantagens específicas. Monografia ( $1^{\circ}$ lugar no II Prêmio Dest/MP). Brasília: 2006.

COUTINHO, L.; BELLUZZO, L. G. Política econômica, inflexões e crise: 1974-1981. In: BELluZZO, L. G.; COUTINHO, R. (Org.). Desenvolvimento capitalista no Brasil: ensaios sobre a crise. São Paulo: Editora Brasiliense, 1984.

CRUZ, P. D. Dívida externa e política econômica: a experiência brasileira nos anos setenta. São Paulo: Editora Brasiliense, 1984.

DEST. Departamento de Coordenação e Governança das Empresas Estatais. Relatório Anual. Disponível em: <www.planejamento.gov.br/controle_estatais/conteudo/publicacoes $>$. Brasília: 1995-2006.

FURTADO, C. Formação econômica do Brasil. Rio de Janeiro: Cia Editora Nacional / Fundo de Cultura, 1979.

GOBETTI, S. As distorções na estimativa dos investimentos públicos decorrentes dos critérios de contabilidade dos governos. Revista do TCU, Brasília, 107, p. 101-109, 2006.

HIRSCHMAN, A. O. The strategy of economic development. New Haven: Yale University Press, 1958.

IBGE. Sistema de Contas Nacionais (Brasil). Série Relatórios Metodológicos. v. 24. Pública. Coordenação de Contas Nacionais. Rio de Janeiro, 2004.

MELlO, M. Privatização e ajuste fiscal no Brasil. Pesquisa e Planejamento Econômico, Rio de Janeiro, IPEA, v. 24, n. 3, dez. 1994.

PINHEIRO, A. C. Privatização no Brasil: por quê? Até onde? Até quando? In: A ECONOMIA brasileira nos anos 90. Rio de Janeiro: BNDES, 1999, p. 147-182.

; GIAMBIAGI, F. Os antecedentes macroeconômicos e a estrutura institucional da privatização no Brasil. In: PINHEIRO, A. C.; FUKASAKU, K. (Org.). A privatização no Brasil: o caso dos serviços de utilidade pública. Rio de Janeiro: BNDES, 2000.

SERRA, J. Ciclos e mudanças estruturais na economia brasileira do pós-guerra. In: BELlUZZO, L. G.; COUTINHO, R. (Org.). Desenvolvimento capitalista no Brasil: ensaios sobre a crise. São Paulo: Editora Brasiliense, 1984.

STN. Série Histórica de Receitas e Despesas. Seção de Contabilidade Governamental: Gestão orçamentária, financeira e patrimonial. Brasília: Secretaria do Tesouro Nacional, 2007. Disponível em: <www.st.fazenda.gov.br>.

VELASCO JR, L. Privatizações: mitos e falsas percepções. In: A ECONOMIA brasileira nos anos 90. Rio de Janeiro: BNDES, 1999, p. 183-216.

WERNECK, R. Poupança estatal, dívida externa e crise financeira do setor público. Pesquisa e Planejamento Econômico, Rio de Janeiro, Ipea, v. 16, n. 3, p. 551-574, 1986. 


\section{Anexo 1}

Execução do Programa de Dispêndios Globais das Empresas Estatais (1995-2006)

\begin{tabular}{|c|c|c|c|c|c|c|c|c|c|c|c|c|}
\hline Consolidado (s/dependentes) & 1995 & 1996 & 1997 & 1998 & 1999 & 2000 & 2001 & 2002 & 2003 & 2004 & 2005 & 2006 \\
\hline Pessoal e Encargos Sociais & 46.806 & 44.353 & 39.671 & 35.328 & 32.967 & 29.691 & 26.385 & 25.452 & 23.654 & 26.044 & 28.326 & 30.234 \\
\hline uros e Outros & 89.032 & 58.390 & 59.437 & 76.821 & 81.559 & 50.400 & 60.940 & 103.164 & 60.924 & 77.936 & 56.085 & 57.652 \\
\hline ODC & 93.268 & 96.218 & 97.221 & 94.309 & 100.422 & 133.862 & 159.131 & 213.178 & 192.311 & 218.432 & 214.682 & 230.583 \\
\hline Materiais e Produ & 29.462 & 29.987 & 21.473 & 16.413 & 27.389 & 43.098 & 45.342 & 63.541 & 50.910 & 67.053 & 57.767 & 64.761 \\
\hline Locação Equipamen & 249 & 176 & 153 & 222 & 215 & 195 & 178 & 140 & 147 & 180 & 216 & 230 \\
\hline Serviços Terce & 17.846 & 18.695 & 17.907 & 18.733 & 15.964 & 18.321 & 20.726 & 22.191 & 24.589 & 26.595 & 30.926 & 33.722 \\
\hline Utilidades e Serviços & 2.309 & 2.235 & 1.968 & 2.056 & 1.810 & 2.092 & 2.149 & 2.531 & 2.490 & 3.123 & 2.811 & 2.860 \\
\hline Tributos e Encar & 30.987 & 34.504 & 42.236 & 41.127 & 31.207 & 46.379 & 58.775 & 72.544 & 73.528 & 79.425 & 80.874 & 81.601 \\
\hline Demais Dispêndios Corr & 12.416 & 10.621 & 13.484 & 15.758 & 23.836 & 23.778 & 31.961 & 52.232 & 40.648 & 42.056 & 42.088 & 47.408 \\
\hline Investimentos & 22.459 & 27.842 & 30.754 & 27.542 & 16.227 & 17.496 & 20.310 & 26.223 & 26.488 & 30.013 & 29.774 & 33.504 \\
\hline Inversões Finan & 1.856 & 4.894 & 8.736 & 8.004 & 12.974 & 5.488 & 2.938 & 12.162 & 5.134 & 5.655 & 2.708 & 4.746 \\
\hline Amortizações & 18.083 & 15.864 & 16.498 & 26.577 & 40.879 & 21.403 & 31.214 & 35.952 & 34.949 & 35.436 & 32.996 & 34.378 \\
\hline Outros Dispêndios Capital** & 3.906 & 18.536 & 12.149 & 33.122 & 17.265 & 14.155 & 97.455 & 25.266 & 22.332 & 24.309 & 25.892 & 24.552 \\
\hline Número Empregados $* * *$ & 531.544 & 469.727 & 443.706 & 349.327 & 339.120 & 324.886 & 333.325 & 340.776 & 352.858 & 368.120 & 383.028 & 398.686 \\
\hline Média Mensal/Empregado**** & $\mathrm{R} \$ 6.774$ & $\mathrm{R} \$ 7.263$ & $\mathrm{R} \$ 6.878$ & $\mathrm{R} \$ 7.779$ & $\mathrm{R} \$ 7.478$ & $\mathrm{R} \$ 7.030$ & $\mathrm{R} \$ 6.089$ & $\mathrm{R} \$ 5.745$ & $\mathrm{R} \$ 5.157$ & $\mathrm{R} \$ 5.442$ & $\mathrm{R} \$ 5.689$ & $\mathrm{R} \$ 5.833$ \\
\hline
\end{tabular}

(*) Inclui pagamento de royalties do setor produtivo. $\quad$ (***) Exclui empregados das estatais dependentes do OGU, que não entram no PDG

(**) Inclui dividendos distribuídos e reaplicados. $\quad(* * * *)$ Custo médio por empregado, incluindo encargos sociais.

Fonte: Elaboração Própria (origem: Dest/PDG/Dados Consolidados/Usos e Fontes/SPE+IFOF). 
Sérgio Wulff Gobetti

\section{Anexo 2}

Evolução das despesas com pessoal das empresas estatais (1995-2006)

\begin{tabular}{|c|c|c|c|c|c|c|c|c|c|c|c|c|}
\hline Setor Produtivo Estatal & 1995 & 1996 & 1997 & 1998 & 1999 & 2000 & 2001 & 2002 & 2003 & 2004 & 2005 & 2006 \\
\hline $\begin{array}{l}\text { Pessoal e Encargos } \\
\text { Sociais }\end{array}$ & 23.731 & 22.748 & 19.329 & 16.101 & 10.786 & 10.573 & 10.457 & 10.497 & 10.811 & 13.081 & 14.762 & 16.033 \\
\hline Número Empregados*** & 352.556 & 306.613 & 273.178 & 191.384 & 180.017 & 174.604 & 187.098 & 193.072 & 201.593 & 211.703 & 216.594 & 228.785 \\
\hline $\begin{array}{l}\text { Média Mensal/ } \\
\text { Empregado**** }\end{array}$ & $\mathrm{R} \$ 5.178$ & $\mathrm{R} \$ 5.707$ & $\mathrm{R} \$ 5.443$ & $\mathrm{R} \$ 6.471$ & $\mathrm{R} \$ 4.609$ & $\mathrm{R} \$ 4.658$ & $\mathrm{R} \$ 4.299$ & $\mathrm{R} \$ 4.182$ & $\mathrm{R} \$ 4.125$ & $\mathrm{R} \$ 4.753$ & $\mathrm{R} \$ 5.243$ & $\mathrm{R} \$ 5.391$ \\
\hline Instituições Financeiras & 1995 & 1996 & 1997 & 1998 & 1999 & 2000 & 2001 & 2002 & 2003 & 2004 & 2005 & 2006 \\
\hline $\begin{array}{l}\text { Pessoal e Encargos } \\
\text { Sociais }\end{array}$ & 23.076 & 21.605 & 20.342 & 19.228 & 22.181 & 19.118 & 15.928 & 14.955 & 12.843 & 12.962 & 13.564 & 14.201 \\
\hline Número Empregados $* * *$ & 178.988 & 163.114 & 170.528 & 157.943 & 159.103 & 146.826 & 146.227 & 147.704 & 151.265 & 156.415 & 166.434 & 169.901 \\
\hline $\begin{array}{l}\text { Média Mensal/ } \\
\text { Empregado**** }\end{array}$ & $\mathrm{R} \$ 9.917$ & $\mathrm{R} \$ 10.189$ & $\mathrm{R} \$ 9.176$ & $\mathrm{R} \$ 9.364$ & $\mathrm{R} \$ 10.724$ & $\mathrm{R} \$ 10.016$ & $\mathrm{R} \$ 8.379$ & $\mathrm{R} \$ 7.788$ & $\mathrm{R} \$ 6.531$ & $\mathrm{R} \$ 6.375$ & $\mathrm{R} \$ 6.269$ & $\mathrm{R} \$ 6.429$ \\
\hline Empresas Dependentes & 1995 & 1996 & 1997 & 1998 & 1999 & 2000 & 2001 & 2002 & 2003 & 2004 & 2005 & 2006 \\
\hline $\begin{array}{l}\text { Pessoal e Encargos } \\
\text { Sociais }\end{array}$ & 2.878 & 3.052 & 2.801 & 2.719 & 2.536 & 2.500 & 2.636 & 2.566 & 2.704 & 2.252 & 2.239 & 2.378 \\
\hline Número Empregados*** & 50.609 & 43.872 & 40.126 & 36.517 & 34.909 & 32.588 & 31.073 & 29.770 & 29.969 & 30.838 & 31.604 & 32.378 \\
\hline $\begin{array}{l}\text { Média Mensal/ } \\
\text { Empregado**** }\end{array}$ & $\mathrm{R} \$ 4.374$ & $\mathrm{R} \$ 5.351$ & $\mathrm{R} \$ 5.369$ & $\mathrm{R} \$ 5.728$ & $\mathrm{R} \$ 5.588$ & $\mathrm{R} \$ 5.900$ & $\mathrm{R} \$ 6.526$ & $R \$ 6.631$ & $\mathrm{R} \$ 6.941$ & $\mathrm{R} \$ 5.617$ & $\mathrm{R} \$ 5.450$ & $\mathrm{R} \$ 5.650$ \\
\hline Total Empregados & 582.153 & 513.599 & 483.832 & 385.844 & 374.029 & 354.018 & 364.398 & 370.546 & 382.827 & 398.956 & 414.632 & 431.064 \\
\hline
\end{tabular}

(*) Inclui pagamento de royalties do setor produtivo. $\quad$ (***) Exclui empregados das estatais dependentes do OGU, que não entram no PDG

$(* *)$ Inclui dividendos distribuídos e reaplicados. $\quad(* * * *)$ Custo médio por empregado, incluindo encargos sociais.

Fonte: Elaboração Própria (origem: Dest/PDG/Dados Consolidados/Usos e Fontes/SPE+IFOF). 